\title{
DURASI DAN FREKUENSI PENGGUNAAN GAWAI TERHADAP PERKEMBANGAN SOSIAL ANAK PRA SEKOLAH DI TK ISLAM PERMATA HATI KELAPA DUA KABUPATEN TANGERANG TAHUN 2019
}

\author{
Yenny Aulya ${ }^{1}$, Suprihatin ${ }^{2}$, Ririn Arantika ${ }^{3}$ \\ 1,2,3Program Studi Kebidanan, Fakultas IImu Kesehatan ,Universitas Nasional \\ 1email: yenny.aulya@civitas.unas.ac.id \\ 2email: atin_bio@yahoo.com \\ 3email: Arantikaririn@gmail.com
}

\begin{abstract}
Background: In 2011 there were 38\% of gadget users in children aged 5 years in Indonesia and in 2013 increased to $72 \%$. The use of devices makes children lazy to move and activities. This situation will affect the child's development both in terms of physical, motor, psychological, and social child.

Objective: To identify the relationship between the duration and frequency of using a device to the social development of preschool children in the Permata Hati Hati Dua Islamic Kindergarten, Tangerang Regency in 2019.

Methodology: This research is an analytic epidemiological study with cross sectional study design. The population in this study were all parents of students at the Permata Hati Kindergarten, totaling 54 people. Sampling uses total sampling. Primary data were collected using a questionnaire. Data analysis through two stages, namely univariate and bivariate using the Chi-Square test.

Results: The majority of pre-school children had poor social development (55.6\%), with duration of playing devices $>1$ hour / day (53.7\%), and frequency of use of devices> 3 days a week (55.6 \%). The results of this study indicate that there is a significant relationship between the duration and frequency of use of the device to the social development of children.

Conclusions : There is a relationship between the duration and frequency of the use of the device to the social development of pre-school children.

Suggestion : It is hoped that parents will be more selective in giving toys to children, especially granting permission to play devices. It is necessary to be firm and mentor from parents in providing limitations on the duration and frequency of device use by children
\end{abstract}

Keywords: Duration, frequency, device, social development, preschool children

\section{ABSTRAK}

Latar Belakang : Tahun 2011 terdapat 38\% pengguna gawai pada anak usia 5 tahun di Indonesia dan pada tahun 2013 meningkat menjadi 72\%. Penggunaan gawai membuat anak menjadi malas bergerak dan beraktifitas. Keadaan seperti ini akan mempengaruhi perkembangan anak baik dari segi fisik, motorik, psikologis, dan sosial anak.

Tujuan : Untuk mengidentifikasi hubungan durasi dan frekuensi penggunaan gawai terhadap perkembangan sosial anak prasekolah di TK Islam Permata Hati Kelapa Dua Kabupaten Tangerang Tahun 2019.

Metodologi : Penelitian ini merupakan penelitian epidemiologi analitik dengan desain studi cross sectional. Populasi dalam penelitian yaitu seluruh orang tua siswa di TK Islam Permata Hati yang berjumlah 54 orang. Pengambilan sampel menggunakan total sampling. Data primer dikumpulkan dengan menggunakan kuesioner. Analisis data melalui dua tahapan yaitu univariat dan bivariat dengan menggunakan uji Chi-Square.

Hasil Penelitian : Sebagian besar anak pra sekolah memiliki perkembangan sosial yang kurang baik $(55,6 \%)$, dengan durasi bermain gawai $>1$ jam/hari $(53,7 \%)$, dan frekuensi penggunaan gawai $>3$ hari dalam seminggu $(55,6 \%)$. Hasil penelitian ini menunjukkan bahwa terdapat hubungan yang signifikan antara durasi dan frekuensi penggunaan gawai terhadap perkembangan sosial anak.

Simpulan : Ada hubungan durasi dan frekuensi penggunaan gawai terhadap perkembangan sosial anak pra sekolah. 
Saran Diharapkan orang tua lebih selektif dalam memberikan mainan kepada anak,terutama pemberian izin bermain gawai.Perlu Ketegasan dan pendampingan dari orang tua dalam memberi Batasan durasi dan frekuensi penggunaan gawai oleh anak

Kata Kunci : Durasi, Frekuensi, Gawai, Perkembangan sosial, Anak Prasekolah

\section{PENDAHULUAN}

Berdasarkan hasil riset statistika bahwa sebanyak $17 \%$ anak berusia dibawah 8 tahun di Amerika Serikat menggunakan komputer, tablet, dan smartphone setiap hari, angka ini merupakan satu per tiga dari jumlah anak yang menghabiskan aktivitas sehari-harinya dengan membaca buku oleh orang tuanya (Ammarullah, 2013). Selain itu seperti dilansir huffingtonpost, sebuah organisasi nirbala Joan Ganz Cooney Centerand Sesame workshop melaporkan bahwa $23 \%$ orang tua memiliki buah hati berusia 0-5 tahun mengaku bahwa anak-anak mereka gemar menggunakan internet. Berdasarkan angka tersebut $82 \%$ orang tua melaporkan bahwa balita mereka online setidaknya sekali dalam seminggu (Vemale, 2013). Di Indonesia sendiri lebih dari 50\% pengguna gawai berumur dibawah 25 tahun. Dewasa atau lanjut usia ( 25 tahun keatas) $32 \%$, remaja (12-21 tahun) $25 \%$, anak-anak (7-11 tahun) $17 \%$, dan lebih ironisnya lagi gawai digunakan oleh anak usia (3-6 tahun) sekitar 9\%, yang seharusnya belum layak untuk menggunakan gawai (Widiawati , \& Sugiman, 2014).

Anak indonesia menggunakan media gawai pada usia 5 tahun sebanyak 38\% pada tahun 2011 dan meningkat menjadi $72 \%$ pada tahun 2013. Salah satu faktor yang mendasari meningkatnya presentase tersebut yaitu karena semakin berkembangnya tekhnologi dengan sistem touch screen yang membuat penggunaan gawai lebih mudah, terlebih bagi anak kecil yang belum bisa baca sekalipun (Rideout, 2016 dalam Gunawan, 2017).

Kemudahan anak dalam mengakses media informasi dan teknologi menjadikan anak malas bergerak dan beraktivitas. Mereka lebih memilih untuk duduk dan menikmati dunia yang ada di dalam gawai tersebut. Hal ini akan berpengaruh terhadap perkembangan anak, baik dari segi fisik, motorik, psikologis maupun sosial anak. Dan anak akan lebih sulit berkonsentrasi pada dunia nyata karena mereka sudah terbiasa dengan dunia digitalnya (Ameliola, \& Nugraha, 2013).

Penelitian yang dilakukan oleh Delima (2015) diperoleh 94\% orang tua menyatakan bahwa anak mereka biasa menggunakan perangkat teknologi untuk bermain game, $63 \%$ anak menghabiskan waktu maksimum 30 menit untuk sekali bermain game, sementara $15 \%$ orang tua menyatakan bahwa anak bermain game selama 30 60 menit dan sisanya dapat bermain game lebih dari satu jam (Yusmi, 2015).

Menurut hasil studi pendahuluan yang dilakukan pada tanggal 25 April 2019, di TK Islam Permata Hati Kelapa Dua Kabupaten Tangerang di dapatkan hasil bahwa 7 dari 10 responden orang tua wali murid mengatakan bahwa anaknya sudah mengenal gawai dan bermain gawai selama rentang waktu 30 menit hingga 5 jam sehari ketika berada di rumah. 7 responden artinya hampir $70 \%$ tersebut mengeluhkan bahwa anaknya semakin susah diingatkan semenjak mengenal gawai. Ada 3 responden artinya hampir $30 \%$ sudah mengerti akan bahayanya pengunaan gawai yang terlalu sering pada anak, sehingga membatasi anak berinteraksi dengan perangkat teknologi.

Berdasarkan latar belakang masalah di atas, maka peneliti tertarik untuk mengetahui hubungan durasi dan frekuensi penggunaan gawai terhadap perkembangan sosial di TK Islam Permata Hati Kelapa Dua Kabupaten Tangerang.

\section{METODOLOGI}

\section{Tempat dan Waktu Penelitian}

Penelitian ini dilakukan di TK Islam Permata Hati, Kecamatan Kelapa Dua, Kabupaten Tangerang Banten. Waktu penelitian pada Bulan Mei-Agustus tahun 2019.

\section{Prosedur Penelitian}

Penelitian ini dilaksanakan dengan empat tahap yaitu (1) pengumpulan data, (2) tabulasi data, (3) analisis data, dan (4) penarikan kesimpulan dan saran.

Penelitian tentang pengaruh hubungan durasi dan frekuensi penggunaan gawai terhadap perkembangan sosial anak pra sekolah di Tk Islam Permata Hati Kelapa Dua Kabupaten Tangerang ini menggunakan pendekatan kuantitatif, dengan metode deskriptif dan jenis penelitian ex post facto. Teknik pengumpulan data dengan angket/kuesioner, observasi dan wawancara.

Populasi dalam penelitian ini adalah seluruh orang tua atau wali dari siswa Taman Kanak-kanak 
(TK) Islam Permata Hati Kelapa Dua Kabupaten Tangerang sejumlah 54 orang.

Instrumen yang digunakan menggunakan kuesioner mengenai hubungan durasi dan frekuensi penggunaan gawai terhadap dampak perkembangan sosial anak prasekolah. Kuesioner yang dibuat untuk durasi dan frekuensi penggunaan gawai masing-masing terdiri dari 1 pertanyaan, kuesioner yang dibuat untuk perkembangan sosial terdiri dari 15 pertanyaan.

Teknik analisis data yang digunakan ada dua, yaitu teknik analisis deskriptif dan teknik analisis statistik. Teknik analisis deskiptif digunakan untuk mengolah data hasil angket/kuesioner, hasil observasi dan hasil wawancara sedangkan teknik analisis statistik digunakan untuk mengolah data hasil angket/kuesioner dan menguji hipotesi penelitian. Teknik analisis statistik yang digunakan dibagi menjadi analisis univariat yang mendeskripsikan masing-masing variabel dan karakteristik responden, serta analisis bivariat digunakan untuk mencari tahu hubungan durasi dan frekuensi penggunaan gawai terhadap perkembangan sosial anak prasekolah. Analisis data tersebut akan menggunakan uji Chi-Square dengan taraf signifikansi $\alpha=5 \%(0,05)$.

\section{HASIL DAN PEMBAHASAN}

Hasil penelitian tentang pengaruh hubungan durasi dan frekuensi penggunaan gawai terhadap perkembangan sosial anak pra sekolah di Tk Islam Permata Hati Kelapa Dua Kabupaten Tangerang berdasarkan hasil perhitungan angket/kuesioner, diperoleh data sebagai berikut.

\section{Analisis Univariat}

\section{Tabel 1 \\ Distribusi Frekuensi Perkembangan Sosial Pada Siswa di TK Islam Permata Hati Kelapa Dua Kabupaten Tangerang Tahun $2019(n=54)$}

\begin{tabular}{ccc}
\hline $\begin{array}{c}\text { Perkembangan } \\
\text { Sosial }\end{array}$ & Frekuensi & Presentase \\
\hline Baik & 24 & $44,4 \%$ \\
Kurang Baik & 30 & $55,6 \%$ \\
Jumlah & 54 & $100 \%$ \\
\hline
\end{tabular}

Berdasarkan Tabel 1 diketahui dari 54 responden didapatkan hasil bahwa mayoritas perkembangan sosial anak kurang baik yaitu sebanyak 30 anak $(55,6 \%)$.

Berdasarkan hasil penelitian didapatkan hasil bahwa perkembangan sosial siswa-siswa di TK Islam Permata Hati Kelapa Dua Kabupaten Tangerang sebagian besar memiliki perkembangan sosial yang kurang baik dengan persentase $55,6 \%$ atau 30 sebanyak dari 54 responden dan 24 dari 54 anak $(44,4 \%)$ memiliki perkembangan sosial yang baik.

Perkembangan sosial merupakan kemampuan berperilaku yang sesuai dengan tuntutan sosial dan mampu bersosialisasi dengan memerlukan tiga proses sebagai berikut dengan baik, anak-anak harus menyukai orang dan aktivitas sosial, jika mereka berhasil melakukannya maka akan dapat menyesuaikan diri dengan baik dan akan diterima sebagai anggota kelompok (Sofyan, 2014). Susanto (2014) mengemukakan bahwa pada usia anak-anak, mereka mulai bergaul atau hubungan sosial baik dengan orang tua, anggota keluarga, orang dewasa lainnya, maupun teman bermainnya, anak mulai mengembangkan bentukbentuk tingkah laku sosial seperti pembangkangan, agresi, berselisih atau bertengkar, mengejek, persaingan, kerja sama.

Perkembangan sosial anak yang kurang baik dapat dilihat dari orang tua yang bekerja di luar rumah sehingga tidak dapat memantau hal yang dilakukan oleh anaknya karena orang tua tidak menghabiskan waktu dengan anaknya. Selain itu kadangkala orang tua sengaja memberikan gawai kepada anak mereka agar anak mereka tidak bermain di luar rumah dan bahkan tidak mengganggu aktivitas orang tua pada saat di rumah. Hal ini membuat anak malas bergerak dan beraktivitas, kurang berinteraksi dengan lingkungannya dan menghambat proses sosialisasi anak karena asyik dengan gawainya dan kelamaan anak dapat merasa bergantung/kecanduan pada gawai tersebut sehingga akan mempengaruhi perkembangan anak menjadi kurang baik (Sapardi, 2018).

Hasil penelitian oleh Triastutik (2018) bermain gawai pada anak usia 4-6 tahun hanya digunakan untuk bermain game dan melihat youtube saja sehingga mereka tidak aktif dalam berinteraksi dengan lingkungan sekitarnya sejalan dengan teori Ismanto (2015) dimana mereka lebih bermain menggunakan gawai dari pada bermain bersama teman-teman dilingkungan sekitar tempat tinggalnya. Sehingga interaksi sosial antara anak dengan masyarakat, lingkungan sekitar berkurang, bahkan semakin luntur.

Velderman (2010) dalam penelitiannya menjelaskan bahwa sekitar 8 sampai 9\% anak prasekolah mengalami masalah psikososial khususnya masalah sosial-emosional seperti kecemasan, susah beradaptasi, susah bersosialisasi, susah dipisah dari orang tua, anak suka sulit diatur, dan perilaku agresif merupakan 
masalah yang sering muncul pada anak usia prasekolah.

Peneliti berasumsi bahwa hal tersebut dapat dilihat dari hasil jawaban kuesioner yang telah diisi oleh responden, sebagian besar responden menyatakan setuju bahwa anak mereka akan marah dan menangis apabila tidak diberikan izin bermain gawai, anak akan marah apabila diganggu ketika bermain gawai, anak akan marah apabila gawai yang dimainkannya di minta oleh orang tua, meskipun dengan alasan dan penjelasan yang baik dari orang tua. Selain itu, mereka juga setuju dengan pernyataan bahwa anak selalu ingin terlihat lebih pandai dalam hal bermain gawai dibandingkan teman-temannya, serta anak pernah berselisisih dengan keluarga, teman atau saudara seusianya gara-gara berebut gawai. Diharapkan orang tua dapat memantau perkembangan anaknya, hal yang dilakukan oleh anaknya dan dapat menghabiskan waktu dengan anaknya serta membatasi waktu yang jelas dalam bermain gawai.

Berdasarkan Tabel 4.1 diketahui bahwa sebagian besar anak-anak di TK Islam Permata Hati Kelapa Dua Kabupaten Tangerang memiliki kebiasaan bermain gawai dengan rentan waktu lebih dari 1 jam dalam setiap harinya. Hal tersebut dapat dilihat dari persentase hasil penelitian yang menunjukkan bahwa sebanyak $53,7 \%$ atau 29 dari 54 orang responden mengatakan bahwa anak mereka memiliki kebiasaan bermain gawai lebih dari 1 jam dalam setiap harinya, sedangkan anak yang bermain gawai kurang dari 1 jam sebanyak 25 atau sebesar $46,3 \%$.

Gawai adalah sebuah benda (alat atau barang elektronik) teknologi kecil yang memiliki fungsi khusus, tetapi sering diasosiasikan sebagai sebuah inovasi atau barang baru (Ma'ruf 2015). Keberadaan gawai di era yang semakin berkembang ini memberikan dampak positif maupun negatif bagi penggunaannya, baik pengguna di usia anak-anak ataupun dewasa. Salah satu faktor yang berperan dalam pemberian dampak gawai yaitu durasi penggunaannya.

Menurut penelitian yang dilakukan oleh Rideout (2013) didapatkan hasil bahwa anak usia 2 sampai 4 tahun telah menghabiskan waktunya di depan layar selama 1 jam 58 menit perharinya dan anak usia 5 hingga 8 tahun menghabiskan waktu di depan layar selama 2 jam 21 menit setiap harinya. $\mathrm{Hal}$ ini bertentangan dengan pendapat Starburger (2011) yang menyatakan bahwa anak hanya boleh berada di depan layar $\leq 1$ jam setiap harinya.

Menurut penelitian sebelumnya, yang dilakukan oleh Salsabila (2016) mengatakan bahwa lama atau durasi penggunaan gawai oleh anak- anak dapat memberikan pengaruh terhadap perkembangannya. Hal tersebut didukung oleh hasil penelitian Novitasari \& Khotimah (2016) bahwa pengenalan gawai terlalu dini pada anak dapat mempengaruhi interaksi sosial anak.

Berdasarkan hasil tersebut, peneliti berasumsi bahwa lamanya durasi penggunaan gawai dapat mengganggu perkembangan, dan ketidakmampuan anak dalam bergaul dan beradaptasi sehingga anak tidak dapat merespon hal yang ada di sekelilingnya dengan baik. Diharapkan orang tua membatasi waktu untuk bermain dengan media elektronik agar anak dapat melakukan kegiatan lain seperti membaca, aktivitas fisik dan bersosialisasi dengan orang lain.

Tabel 2

Distribusi Frekuensi Durasi Penggunaan Gawai Pada Siswa di TK Islam Permata Hati Kelapa Dua Kabupaten Tangerang Tahun 2019 ( $n=54)$

\begin{tabular}{ccc}
\hline $\begin{array}{c}\text { Durasi } \\
\text { Penggunaan Gawai }\end{array}$ & Frekuensi & Presentase \\
\hline Normal ( $\leq 1 \mathrm{Jam})$ & 24 & $44,4 \%$ \\
Lama (>1 Jam) & 30 & $55,6 \%$ \\
Jumlah & 54 & $100 \%$ \\
\hline
\end{tabular}

Berdasarkan Tabel 2 diketahui dari 54 responden didapatkan hasil bahwa mayoritas anakanak bermain gawai lebih dari 1 jam setiap harinya yaitu sebanyak 29 anak (53,7\%).

Berdasarkan hasil penelitian didapatkan sebagian besar anak-anak di TK Islam Permata Hati Kelapa Dua Kabupaten Tangerang memiliki kebiasaan bermain gawai dengan frekuensi penggunaan gawai lebih dari 3 hari dalam satu minggu. Hal tersebut dapat dilihat dari persentase hasil penelitian yang menunjukan bahwa sebanyak $55,6 \%$ atau 30 dari 54 orang responden mengatakan bahwa anak mereka memiliki frekuensi lebih sering bermain gawai lebih dari 3 hari dalam satu minggu.

Frekuensi penggunaan gawai sangat mempengaruhi perilaku komunikasi individu. Kini gawai sudah menjadi media komunikasi pokok. Hal tersebut dibuktikan dengan kenyataan di lapangan. Semua orang pasti tidak bisa lepas dari gawai, baik dalam berkomunikasi ataupun sekedar mengunggah di media sosial. Hal tersebut memperlihatkan bahwa intensitas penggunaan gawai berpengaruh terhadap perubahan perilaku individu demikian juga pada balita (Chikmah, \& Fitrianingsih, 2018).

Menurut hasil observasi penelitian yang dilakukan oleh Trinika (2015) frekuensi penggunaan 
gawai paling sedikit 1 sampai 3 hari per minggu, 4 sampai 6 hari per minggu dan setiap hari menggunakan gawai. Anak-anak yang frekuensi penggunaan gawainya terlalu sering dapat kehilangan kemampuan perubahan dasar dalam berkomunikasi yaitu memahami ekspresi yang menandai perubahan seseorang. Padahal kemampuan tersebut adalah salah satu modal penting saat berinteraksi langsung (Pangastuti, 2017).

Asumsi peneliti bahwa frekuensi gawai yang terlalu sering akan dapat mengganggu perkembangan terutama perkembangan sosial, komunikasi dapat terganggu, sehingga orang tua harus membatasi frekuensi penggunaan gawai dan lebih mengawasi serta menemani anak semakin banyak, dan waktu anak bermain gawai juga dapat lebih terkontrol. Diharapkan orang tua untuk melatih motorik kasar misalnya berenang, main futsal, taekwondo, berlari, atau bahkan menari.

Berdasarkan hasil penelitian ini, dapat dilihat pula bahwa $27,6 \%$ atau 8 dari 29 anak yang terlalu lama bermain gawai memiliki perkembangan sosial yang baik. Hal tersebut dikarenakan perkembangan sosial pada anak dipengaruhi oleh banyak faktor, tidak hanya dari stimulasi bermain gawainya saja.

Analisa data penelitian ini menggunakan uji Chi-Square pada Tabel 4.4 dengan tingkat kesalahan (alpha) $5 \%$ atau 0,05 . Setelah dilakukan perhitungan, didapatkan nilai Chi-Square $(p=0,016)$ yang berati $p$ value $<0,05$. Maka dapat disimpulkan bahwa Ho ditolak dan Ha diterima, artinya ada hubungan antara durasi penggunaan gawai terhadap perkembangan sosial anak pra sekolah di TK Islam Permata Hati Kelapa Dua Kabupaten Tangerang.

Mayar (2013) mengemukakan bahwa perkembangan sosial anak sangat tergantung pada individu anak, peran orang tua, serta lingkungan yang ada di sekitar anak. Masing-masing orang tua memiliki cara tersendiri dalam mendidik dan membimbing anak.

Hasil penelitian ini sesuai dengan penelitian sebelumnya yang dilakukan oleh Salsabila (2016) mengenai pengaruh lama penggunaan gawai terhadap perkembangan anak di TK Al Azhar Banda Aceh. Pada penelitian tersebut dijelaskan bahwa kebiasaan bermain gawai pada anak dapat mempengaruhi perkembangannya. Hasil dari penelitian tersebut dapat disimpulkan bahwa semakin sering seorang anak bermain gawai maka semakin tinggi pula resiko terkena gangguan perkembangan. Dampak dari gangguan pekembangan tidak hanya akan terlihat dalam jangka pendek, akan tetapi semakin terlihat pada jangka panjang selama proses perkembangan anak. Karena bagaimanapun masa kanak-kanak merupakan periode awal dari berkembangnya manusia. Apabila seorang anak tidak mampu meraih potensinya secara maksimal, maka di masa dewasanya kelak juga tidak mampu menjadi seseorang yang produktif.

Asumsi peneliti menyatakan hal tersebut dikarenakan pemakaian gawai yang terlalu lama dapat berdampak bagi kesehatan anak, gejala seperti mata kering atau lelah yang menyebabkan sakit kepala akibat paparan blue light berlebih dan bisa menyebabkan kebutaan, dan semakin banyak waktu yang digunakan anak untuk menatap layar gawai atau melakukan aktivitas dekat lainnya, dapat mempercepat mata minus, plus, maupun silinder pada anak yang sudah berkaca mata. Selain radiasinya yang berbahaya, penggunaan gawai yang terlalu lama dapat mempengaruhi tingkat agresif pada anak. Selain itu, anak menjadi tidak peka terhadap lingkungan di sekelilingnya. Anak yang terlalu asik dengan gawaimya berakibat lupa untuk berinteraksi ataupun berkomunikasi dengan orang sekitar maupun keluarga dan itu akan berdampak buruk bagi perkembangan sosial anak.

Tabel 3

Distribusi Frekuensi Penggunaan Gawai di TK Islam Permata Hati Kelapa Dua Kabupaten Tangerang Tahun $2019(n=54)$

\begin{tabular}{ccc}
\hline Durasi Penggunaan Gawai & Frekuensi & Presentase \\
\hline Normal ( $\leq 3$ hari/minggu) & 24 & $44,4 \%$ \\
Lama (> 3 hari/minggu) & 30 & $55,6 \%$ \\
Jumlah & 54 & $100 \%$ \\
\hline
\end{tabular}

Berdasarkan Tabel 3 diketahui dari 54 responden didapatkan hasil bahwa mayoritas anakanak sering bermain gawai lebih dari 3 hari/minggu yaitu sebanyak $(55,6 \%)$.
Hasil penelitian ini menunjukkan bahwa sebagian besar anak yang mengalami perkembangan sosial kurang dari rata-rata adalah anak yang cenderung memiliki kebiasaan bermain gawai lebih dari 3 hari dalam satu minggu yaitu 
sebanyak 22 anak (73,3\%) yang memiliki perkembangan sosial kurang baik dan 8 anak $(44,4 \%)$ yang sering bermain gawai memiliki perkembangan sosial yang baik.

Analisa data penelitian ini menggunakan uji Chi-Square pada Tabel 4.5 dengan tingkat kesalahan (alpha) $5 \%$ atau 0,05. Hasil uji statistik dengan uji Chi-Square nilai $p$ value $=0,008$ yang berati $p$ value $<0,05$. Maka dapat disimpulkan bahwa Ho ditolak dan Ha diterima, artinya ada hubungan antara frekuensi penggunaan gawai terhadap perkembangan sosial anak pra sekolah di TK Islam Permata Hati Kelapa Dua Kabupaten Tangerang.

Hasil penelitian ini sesuai dengan penelitian sebelumnya yang dilakukan oleh Triastutik (2018) mengenai hubungan pengaruh gawai dengan tingkat perkembangan anak usia 4-6 di TK Bina Insani Desa Candimulyo Kecamatan Jombang Kabupaten Jombang pada penelitian tersebut dijelaskan bahwa anak yang jarang menggunakan gawai 14 responden $(51,9 \%)$ dan sering menggunakan gawai 2 responden $(7,4 \%)$ akan mengalami tingkat perkembangan sosial terlambat. Hasil penelitian yang dilakukan oleh peneliti bahwa ada $8(26,7 \%)$ anak yang sering bermain gawai memiliki perkembangan sosial normal. Sesuai hasil penelitian Triastutik (2018) bahwa anak yang tidak pernah atau jarang menggunakan gawai akan mengalami tingkat perkembangan sosial normal dengan jumlah 6 responden (22,2\%). Anak tersebut dapat bermain dengan teman sebaya dan dapat mudah berkomunikasi dengan orang sekitar dengan baik. Anak yang jarang bermain gawai ada yang mengalami tingkat perkembangan sosial normal dan terlambat. Dimana anak tersebut dalam bermain gawai digunakan untuk belajar agar menambah pengetahuan atau dipergunakan dalam hal-hal positif.

Ardita (2012) mengemukakan bahwa banyak faktor yang mempengaruhi pertumbuhan dan perkembangan anak, diantaranya yaitu pendidikan ibu, pendidikan bapak, stimulasi perkembangan anak dan faktor lingkungan dari anak. Salah satu stimulus yang diduga mampu mempengaruhi perkembangan anak, terutama perkembangan sosial yaitu pengenalan gawai terlalu dini pada anak.

Penelitian ini sesuai dengan hasil penelitian Novitasari \& Khotimah (2016) yang menyatakan bahwa pengenalan gawai terlalu dini pada anak dapat mempengaruhi interaksi sosial anak. Penggunaan gawai yang berlebihan atau terlalu sering dapat mempengaruhi kepribadian anak sehingga mudah marah ketika di nasehati, tidak mau mendengarkan nasehat, tidak memperdulikan orang-orang disekitar dan lebih individualisme.

Peneliti berasumsi bahwa frekuensi penggunaan gawai terlalu sering tanpa adanya pengawasan dari orang tua akan memberikan dampak negatif terhadap perkembangan sosial anak. Diharapkan orang tua dapat menambah kualitas interaksi antara anak dan orang tua selama di rumah dan lebih fokus serta terarah untuk mendampingi anaknya saat bermain gawai dan bermain bersama orang tua secara aktif di rumah sehingga perkembangan anak dapat tercapai sesuai usia dan maksimal.

\section{Analisis Bivariat}

Berdasarkan Tabel 4 diabawah ini diketahui bahwa hubungan antara durasi penggunaan gawai yang normal dengan perkembangan sosial anak prasekolah diperoleh dari 16 (64,0\%) dari 25 anak $(46,2 \%)$ tersebut memiliki perkembangan sosial yang baik. Begitupun sebaliknya, penggunaan gawai oleh anak dengan durasi yang lama, akan berdampak pada perkembangan sosial anak. Hal tersebut dapat dilihat dari hasil penelitian yang menunjukkan bahwa terdapat $21(72,4 \%)$ dari 29 anak $(53,7 \%)$ yang lama bermain gawai, memiliki perkembangan sosial yang kurang baik.

Tabel 4

Hubungan Durasi Penggunaan Gawai Terhadap Perkembangan Sosial Anak Pra Sekolah di TK Islam Permata Hati Kelapa Dua Kabupaten Tangerang Tahun 2019 ( $n=54)$

\begin{tabular}{|c|c|c|c|c|c|c|c|c|}
\hline \multirow{3}{*}{$\begin{array}{c}\text { Durasi Penggunaan } \\
\text { Gawai }\end{array}$} & \multicolumn{4}{|c|}{ Perkembangan Sosial } & \multirow{2}{*}{\multicolumn{2}{|c|}{ Total }} & \multirow{3}{*}{$P$ Value } & \multirow{3}{*}{$\begin{array}{l}\text { OR }(95 \\
\% \mathrm{Cl})\end{array}$} \\
\hline & \multicolumn{2}{|c|}{ Baik } & \multicolumn{2}{|c|}{ Kurang Baik } & & & & \\
\hline & $F$ & $\%$ & $\mathbf{F}$ & $\%$ & $F$ & $\%$ & & \\
\hline Normal ( $\leq 1$ jam) & 16 & $64,0 \%$ & 9 & $36,0 \%$ & 25 & $100 \%$ & & \\
\hline Lama (> 1 jam) & 8 & $27,6 \%$ & 21 & $72,4 \%$ & 29 & $100 \%$ & 0,016 & 4,661 \\
\hline Total & 24 & $91,6 \%$ & 30 & $108,4 \%$ & 54 & & & \\
\hline
\end{tabular}

Setelah dilakukan perhitungan statistik dengan uji Chi-Square, didapatkan hasil $p$ value sebesar 0,016 maka $p$ value $<0,05$ dapat diambil kesimpulan Ho ditolak dan Ha diterima, yang artinya 
ada hubungan antara durasi penggunaan gawai terhadap perkembangan sosial anak prasekolah di TK Islam Permata Hati Kelapa Dua Kabupaten Tangerang Tahun 2019. Diperoleh Odds Ratio (OR) $=4,667$, oleh karena OR $(4,667)$ lebih besar dari pada 1 maka dapat disimpulkan bahwa durasi penggunaan gawai adalah faktor yang mempengaruhi perkembangan sosial pada anak prasekolah. Nilai $\mathrm{OR}=4,667$ ini memiliki pengertian bahwa durasi yang lama menggunakan gawai mempunyai peluang 4,667 kali untuk mengalami perkembangan sosial kurang baik dibanding anak yang durasi penggunaan gawainya normal.

Tabel 5

Hubungan Frekuensi Penggunaan Gawai Terhadap Perkembangan Sosial Anak Pra Sekolah di TK Islam Permata Hati Kelapa Dua Kabupaten Tangerang Tahun 2019 ( $n=54)$

\begin{tabular}{|c|c|c|c|c|c|c|c|c|}
\hline \multirow{3}{*}{$\begin{array}{c}\text { Frekuensi } \\
\text { Penggunaan Gawai }\end{array}$} & \multicolumn{4}{|c|}{ Perkembangan Sosial } & \multirow{2}{*}{\multicolumn{2}{|c|}{ Total }} & \multirow{3}{*}{$P$ Value } & \multirow{3}{*}{$\begin{array}{l}\text { OR }(95 \\
\% \mathrm{Cl})\end{array}$} \\
\hline & \multicolumn{2}{|c|}{ Baik } & \multicolumn{2}{|c|}{ Kurang Baik } & & & & \\
\hline & $\mathbf{F}$ & $\%$ & $F$ & $\%$ & $F$ & $\%$ & & \\
\hline Normal ( $\leq 3$ hari) & 16 & $66,7 \%$ & 8 & $33,3 \%$ & 24 & $100 \%$ & ח & 5550 \\
\hline Lama (> 3 hari) & 8 & $26,7 \%$ & 22 & $73,3 \%$ & 30 & $100 \%$ & 0,008 & 0,000 \\
\hline Total & 24 & $93,4 \%$ & 30 & $106,6 \%$ & 54 & & & \\
\hline
\end{tabular}

Berdasarkan Tabel 4.5 diketahui bahwa hubungan antara frekuensi penggunaan gawai yang normal dengan perkembangan sosial anak prasekolah diperoleh dari $16(66,7 \%)$ dari 24 anak $(44,4 \%)$ tersebut memiliki perkembangan sosial yang baik. Begitupun sebaliknya, penggunaan gawai oleh anak dengan frekuensi yang terlalu sering, akan berdampak pada perkembangan sosial anak. Hal tersebut dapat dilihat dari hasil penelitian yang menunjukkan bahwa terdapat $22(73,3 \%)$ dari 30 anak $(55,5 \%)$ yang sering bermain gawai, memiliki perkembangan sosial yang kurang baik.

Setelah dilakukan perhitungan statistik dengan uji Chi-Square, didapatkan hasil $p$ value sebesar 0,008 maka $p$ value $<0,05$ dapat diambil kesimpulan Ho ditolak dan Ha diterima, yang artinya ada hubungan antara frekuensi penggunaan gawai terhadap perkembangan sosial anak prasekolah di TK Islam Permata Hati Kelapa Dua Kabupaten Tangerang Tahun 2019. Diperoleh Odds Ratio (OR) $=5,500$, oleh karena OR $(5,500)$ lebih besar dari pada 1 maka dapat disimpulkan bahwa frekuensi penggunaan gawai adalah faktor yang mempengaruhi perkembangan sosial pada anak prasekolah. Nilai $\mathrm{OR}=5,500$ ini memiliki pengertian bahwa frekuensi menggunakan gawai dengan kategori sering mempunyai peluang 5,500 kali untuk mengalami perkembangan sosial kurang baik dibanding anak yang frekuensi penggunaan gawainya normal.

\section{SIMPULAN}

Berdasarkan hasil penelitan mengenai hubungan durasi dan frekuensi penggunaan gawai terhadap perkembangan sosial anak pra sekolah di TK Islam Permata Hati Tangerang Kelapa Dua
Kabupaten Tangerang tahun 2019, maka peneliti dapat menarik kesimpulan sebagai berikut: Sebagian besar anak pra sekolah memiliki perkembangan sosial yang kurang baik $(55,6 \%)$ dikarenakan durasi penggunaan gawai lebih dari 1 jam dalam sehari $(53,7 \%)$ dengan frekuensi lebih dari 3 hari dalam seminggu $(55,6 \%)$.

Terdapat hubungan yang signifikan antara durasi dan frekuensi penggunaan gawai dengan tingkat perkembangan sosial anak pra sekolah.

Dalam penelitian ini variabel yang paling berpengaruh terhadap perkembangan sosial anak pra sekolah adalah frekuensi penggunaan gawai dengan nilai Odds Ratio $(\mathrm{OR})=5,500$.

\section{SARAN}

Diharapkan orang tua lebih selektif dalam memberikan mainan kepada anak,terutama pemberian izin bermain gawai.Perlu Ketegasan dan pendampingan dari orang tua dalam memberi Batasan durasi dan frekuensi penggunaan gawai oleh anak

\section{DAFTAR PUSTAKA}

Al-Ayouby, M.H. 2017. Dampak penggunaan gadget pada anak usia dini di PAUD dan TK Handayani Bandar Lampung. Skripsi, Fakultas IImu Sosial Dan IImu Politik Universitas Lampung, Bandar Lampung.

Amarullah, A. \& Okezone. 2013, Tiap Hari, 17\% Anak Main Gadget. http://berita.plasa.msn.com/article.aspx?cpdocumentid=254350783, diakses 12 April 2019. 
Ameliola, S. \& Nugraha, 2013, Perkembangan Media Informasi dan Teknologi Terhadap Anak dalam Era Globalisasi, http://icssis.files.wordpress.com/2013/09/201 3-0229, diakses 12 April 2019.

Ardita V, Kadir A, \& Askar M. 2012. Deteksi perkembangan anak berdasarkan DDST di RW 1 Kelurahan Luminda Kecamatan Wara Utara Kota Palpopo. Jurnal STIKES, 1(2), 10.

Carolin B .T, Anggita R. S, Vivi S , 2018. Analisis Faktor Yang Mempengaruhi Status Gizi Balita ( 12 - 59 Bulan) Di Puskesmas Kabupaten Tangerang. Jurnal IImu dan Budaya, no 41.

Chikmah, A.M, Fitrianingsih D, 2018. Pengaruh Durasi Penggunaan Gadget Terhadap Masalah Mental Emosional Anak Pra Sekolah di TK Pembina Kota Tegal. Jurnal Siklus, 7(2), 11.

Delima, R., Arianti N.K., dan Pramudyawardani B. 2015. Identifikasi Kebutuhan Pengguna Untuk Aplikasi Permainan Edukasi Bagi Anak Usia 4 sampai 6 Tahun. Jurnal Teknik Informatika dan Sistem Informasi, 1(1), 4-8.

Ferliana, J.M, 2016, Anak dan Gadget Yang Penting Aturan Main. http://nakita.grid.id/balita/anakdengangadgetyang-penting-aturanmain?page=2, diakses 14 Mei 2019 .

Gunawan, M.A.A, 2017. Hubungan Durasi Penggunaan Gadget Terhadap Perkembangan Sosial Anak Prasekolah di TK PGRI 33 Sumurbroto Banyumanik. Skripsi, Semarang: UNDIP.

Ismanto, Yudi \& Onibala, Franly. 2015. Hubungan Penggunaan Gadget Dengan Tingkat Prestasi Siswa Di Sma Negeri 9 Manado. Ejoural Keperawatan Volume 3(2). FK Unsrat Manando.

Ma'ruf, H. 2015. Pengaruh Bermain Game Terhadap Perkembangan Remaja. Serpong: Surya University.

Mayar, F. 2013. Perkembangan sosial anak usia dini sebagai bibit untuk masa depan bangsa. Jurnal Al-Ta'lim. 1(6), 459-464.

Novitasari W \& Khotimah N, 2016. Dampak Penggunaan Gadget Terhadap Interaksi Sosial Anak Usia 5-6 Tahun. Jurnal PAUD Teratai, 5(3), 182-186.
Pangastuti, R. 2017. Fenomena Gadget Dan Perkembangan Sosial Bagi Anak Usia Dini. Indonesian Journal of Islamic Early Childhood Education, 2(2), 8.

Rideout, V. Zero to eight. 2013. Electronic media in the lives of infants, toddlers and prescholers. Common Sense Media Research Study.

Salsabila, S. 2016. Pengaruh lama penggunaan gadget terhadap perkembangan anak di TK Al-Azhar, Skripsi, Program Studi Pendidikan Dokter, Banda Aceh.

Sapardi, V.S. 2018. Hubungan Penggunaan Gadget Dengan Perkembangan Anak Usia Prasekolah di PAUD/TK Islam Budi Mulia. Menara IImu, 12(2), 80.

Sofyan, H. 2014. Perkembangan Anak Usia Dini dan Cara Praktis Peningkatannya. Jakarta: CV. Infomedika.

Starburger, V.C. 2011. Children, adolescents, obesity and the media. Pediatrics.

Sugiyono. 2010. Metode Penelitian Pendidikan Pendekatan Kuantitatif. Kualitatif, dan R\&D. Bandung: Alfabeta.

Susanto, A. 2011. Perkembangan Anak Usia Dini: Pengantar Dalam Berbagai Aspeknya. Jakarta: Kencana.

Susanto, A. 2014. Perkembangan Anak Usia Dini. Jakarta: Kencana Prenadamedia Group.

Triastutik, Y. 2018. Hubungan bermain gadget dengan tingkat perkembangan anak usia 4-6 tahun di Taman Kanak-kanak Bina Insani. Skripsi, Program Studi S1 IImu keperawatan, Jombang.

Trinika, Y.A. Nurfianti, \& Irsan, A. 2015. Pengaruh Penggunaan Gadget Terhadap Perkembangan Psikososial Anak Usia Prasekolah (3-6 Tahun) di TK Swasta Kristen Immanuel. Skripsi, Universitas Tanjungpur. Potianak.

Velderman, M., Crone, M., Wiefferink, C., \& Reijneveld, S. 2010. Identification and management of psychosocial problems among toddlers by preventive child health care professionals. European Journal of Public Health, 20(3), 332-338.

Widiawati, I, \& Sugiman, 2014, Pengaruh penggunaan gadget terhadap daya kembang anak.

http://stmikglobal.ac.id/wpcontent/uploads/20 14/05/ARTIKELIIS.pdf, dikases tanggal 01 Mei 2019. 